\title{
KONTRIBUSI ARTHROPODA KANOPI DALAM MENJAGA STABILITAS EKOSISTEM PADA KEBUN BERBASIS SENGON LAUT (Paraserianthes falcataria (L.) BUDIDAYA PORANG (Amorphophallus muelleri Blumei) (Schott) DI JEMBER SEBAGAI SUMBER BELAJAR BIOLOGI
}

\author{
IVONE WULANDARI BUDIHARTO \\ Pendidikan Biologi FKIP Universitas Muhammadiyah Metro \\ E-mail : ivonewulan@yahoo.com
}

\begin{abstract}
The development of agroforestry based of Sengon Laut with Porang crop area has successfully to increase people economic level. This research aimed to analyze and compare diversity, composition, structure community of canopy Arthropod at two different location (Sengon Laut of Porang crop area and non porang crop area) which was attracted to blue and yellow colored water pan trap, vertical variation diversity, abundance, and structure community of canopy Arthropod, to know the relation between community of Arthropod canopy with abiotic factor at local agroforestry and to recommend good cultivating management. Samples of canopy Arthropod was taken at two different location by blue and yellow colored water pan trap, which was hang on bottom layer (1-1,5 $\mathrm{m}$ ) and upper layer (8-10 m). Abiotic factors (Temperature and light intensity) were measured at each location. Non crop vegetation was analyzed by line intercept method and tree vegetation was analyzed by complete count method. Data of structure community comparison each location was analyzed by important value and diversity (Index Shannon-Whienner). The degree of same level composition between two location was analyzed by Index Bray-Curtis and variation vertical analyzed by anova. Canopy Arthropod composition and relation with abiotic factors was analyzed by Pearson Correlation with MINITAP program. The value abundance of canopy Arthropod in Porang crop area was (329 individu), fewer than canopy Arthropod in non Porang crop area which was (829 individu). The result showed that yellow water pan trap had better efficiency on upper layer at non Porang crop area than porang crop area. Recommendation to the farmers in order to make good cultivation management non crop vegetation is not cleaned and not used pesticide utilization.
\end{abstract}

Kata kunci: Arthropoda kanopi, faktor abiotik, stabilitas ekosistem, sengon laut, budidaya porang

\begin{abstract}
Peningkatan
keanekaragaman

hasil

produksi merupakan tujuan dari pembangunan pertanian pangan di Indonesia khususnya tanaman pangan, Tujuan utama peningkatan ini adalah untuk memenuhi kebutuhan produk-produk bahan pangan serta pendapatan taraf hidup dan kesejahteraan petani. Agroforestri merupakan salah satu contoh kegiatan pemerintah untuk mengatasi permasalahan dalam peningkatan produksi hasil pertanian yang memanfaatkan sumber daya alam, dimana dalam sistem agroforestri yang
\end{abstract}

merupakan pengelolaan lahan hutan tanaman keras berkayu/pohon-pohonan, perdu, jenis-jenis palm, bambu, dsb, ditanam bersamaan dengan tanaman pertanian, dan/atau hewan, dengan suatu tujuan tertentu dalam suatu bentuk pengaturan spasial atau urutan temporal, dan didalamnya terdapat interaksiinteraksi ekologi dan ekonomi diantara berbagai komponen yang bersangkutan.

Kegiatan sistem agroforestri ini dianggap sangat memberikan kontribusi yang baik terhadap tingkat perekonomian masyarakat, sehingga beberapa tahun belakangan ini 
pengembangan sistem agroforestri sudah menjadi tren baru yang di lakukan oleh pihak perhutani di lahan hutan luas maupun oleh masyarakat yang menggunakan lahan kebun disekitar rumah untuk penerapan sistem agroforestri lokal. Contoh agroforestri yang berkontribusi terhadap tingkat perekonomiani masyarakat adalah agroforestri budidaya Porang (Amorphophallus muelleri Blumei) (Schott) di berbagai wilayah misalnya di Kabupaten Madiun dan Jember. Agroforestri budidaya Porang merupakan salah satu kegiatan pemanfaatan hutan Sengon Laut (Paraserianthes falcataria L.) yang pada bagian dasar hutannya dimanfaatkan untuk budidaya tanaman Porang dengan melibatkan masyarakat lokal.

Pemilihan jenis tanaman porang disebabkan oleh adanya kandungan glukomanan yang memiliki potensi yang besar sebagai komoditi ekspor penting dari Jawa Timur serta pemasok bahan baku industri lokal. Zat glukomanan dapat dimanfaatkan sebagai bahan perekat, mie, konyaku-jelly, perekat tablet, pembungkus kapsul, penguat kertas, bahan peledak, kosmetik dan pembersih. Pemilihan tanaman berkayu Sengon Laut (Paraserianthes falcataria) dalam agroforestri ini dikarenakan tanaman Sengon Laut memiliki manfaat yang banyak bagi masyarakat diantaranya yaitu dapat digunakan sebagai bahan perumahan dan pohon Sengon Laut memiliki daun yang sangat baik bagi kesuburan tanah.

Ekosistem lahan agroforesti budidaya Porang memberikan manfaat nyata bagi masyarakat yaitu dapat memberikan jasa layanan ekonomi dan ekologi. Jasa ekonomi yang dimaksud adalah hasil pertanian yang didapatkan dapat meningkatkan perekonomian masyrakat sekitar dan jasa layanan ekologi dalam hal ini adalah lahan agroforestri dapat sebagai penyimpan karbon dan habitat bagi hewan khususnya Arthropoda kanopi dan tumbuhan dimana faktor abiotik sangat berperan penting dalam mendukung kelangsungan hidup dari Arthropoda kanopi. Arthropoda kanopi merupakan komponen biotik yang memiliki peran penting dalam ekosistem hutan. Arthropoda memiliki peranan dalam proses herbivori, predasi, polinasi dan berperan penting mendukung siklus transformasi material dalam suatu ekosistem yang nantinya sangat berkaitan dengan produksi hasil pertanian.

Peranan Arthropoda kanopi dalam kehidupan manusia dapat mempengaruhi hasil dan kualitas hasil pertanian. Arthropoda hama yang merupakan jenis Arthropoda yang secara rutin atau kadang-kadang menyebabkan kerusakan sehingga dapat mengurangi hasil atau kualitas hasil pertanian. Selain itu ada juga jenis Arthropoda kanopi penyerbuk yang dapat membantu manusia dalam penyerbukan tanaman. Manfaat jasa layanan ekonomi yang dapat diberikan oleh lahan agroforestri adalah dapat meningkatkan perekonomian masyarakat dengan pesat melalui sistem pertanian berkelanjutan.

Jember merupakan salah satu wilayah yang memiliki lahan agroforestri budidaya Porang yang besar. Luas lahan agroforestri budidaya Porang di Jember 121,3 Ha. Penelitian yang dilakukan oleh Harjoko et al., (2011) di daerah Jember mendapatkan hasil bahwa terdapat jenis Porang yang mempunyai sifat unggul dan menghasilkan kadar glukomanan serta kandungan pati tinggi sehingga sesuai untuk dibudidayakan berdasarkan karakter morfologi dan molekuler serta mendapatkan variabel agronomis yang paling berpengaruh terhadap pembentukan pati dan glukomanan 
Permasalahan yang sering terjadi pada pengelolaan lahan kebun adalah pengelolaan lahan secara intensif yang dilakukan oleh petani dengan jangka panjang dalam upaya untuk meningkatkan hasil produksi pertanian. Pengelolaan secara intensif yang dimaksud disini adalah pengelolaan lahan yang sering dilakukan oleh para petani yaitu kegiatan pengelolaan yang menggunakan bahan murah, efektif, dan efisien untuk memberikan keuntungan ekonomis dalam rangka pengendalian hama untuk memelihara dan merawat lahan mereka sehingga diperoleh hasil yang baik. Pengelolaan tersebut diantaranya yaitu pengendalian hama menggunakan pestisida kimia dan penyiangan tumbuhan liar (vegetasi non crop) di sekitar lahan kebun berbasis Sengon laut dengan tanaman budidaya Porang yang sering dibersihkan. Keadaan ini dapat menyebabkan stabilitas ekosistem lahan agroforestri menjadi terganggu seperti terjadinya kontaminasi lingkungan, resitensi hama, dan keberadaan musuh alami, Akibatnya terjadi perubahan kelimpahan, diversitas dan struktur komunitas Arthropoda baik kanopi maupun Arthropoda tanah serta tumbuhan menjadi kurang berdaya guna.

\section{METODE}

Penelitian ini bertujuan untuk menganalisis dan membandingkan diversitas, komposisi, struktur komunitas
Arthropoda kanopi pada dua lokasi berbeda (lahan kebun Sengon Laut budidaya Porang dan non Porang) yang tertarik pada perangkap bejana berwarna biru dan kuning, mengetahui variasi vertikal diversitas, kelimpahan dan struktur komunitas Arthropoda kanopi, untuk mengetahui hubungan komunitas Arthropoda kanopi dengan faktor abiotik dan untuk memberikan rekomendasi tentang pengelolaan lahan kebun. Penelitian ini menggunakan rancangan blok dan pemilihan tegakan sebagai titik sampel ditentukan di lokasi penelitian secara (Purposive). Pencuplikan Arthropoda di dua lokasi menggunakan perangkap bejana kuning dan biru digantungkan pada ketinggian kanopi bawah $(1-1,5 \mathrm{~m})$ dan ketinggian kanopi atas $(8-10 \mathrm{~m})$. Pengukuran faktor lingkungan (suhu dan cahaya) dilakukan disetiap lokasi. Analisis vegetasi non crop dilakukan dengan menggunakan metode line intercept dan vegetasi pohon menggunakan metode perhitungan lengkap. Analisis data perbandingan struktur komunitas antar lokasi didapatkan dari nilai penting dan diversitas (indeks Shannon-Wiener). Kesamaan komposisi dua lokasi dianalisis menggunakan (indeks kesamaan Bray-Curtis) dan pola variasi vertikal dianalisis dengan Anova. Komposisi Arthropoda kanopi dan korelasinya dengan faktor lingkungan dianalisis dengan pearson correlation.

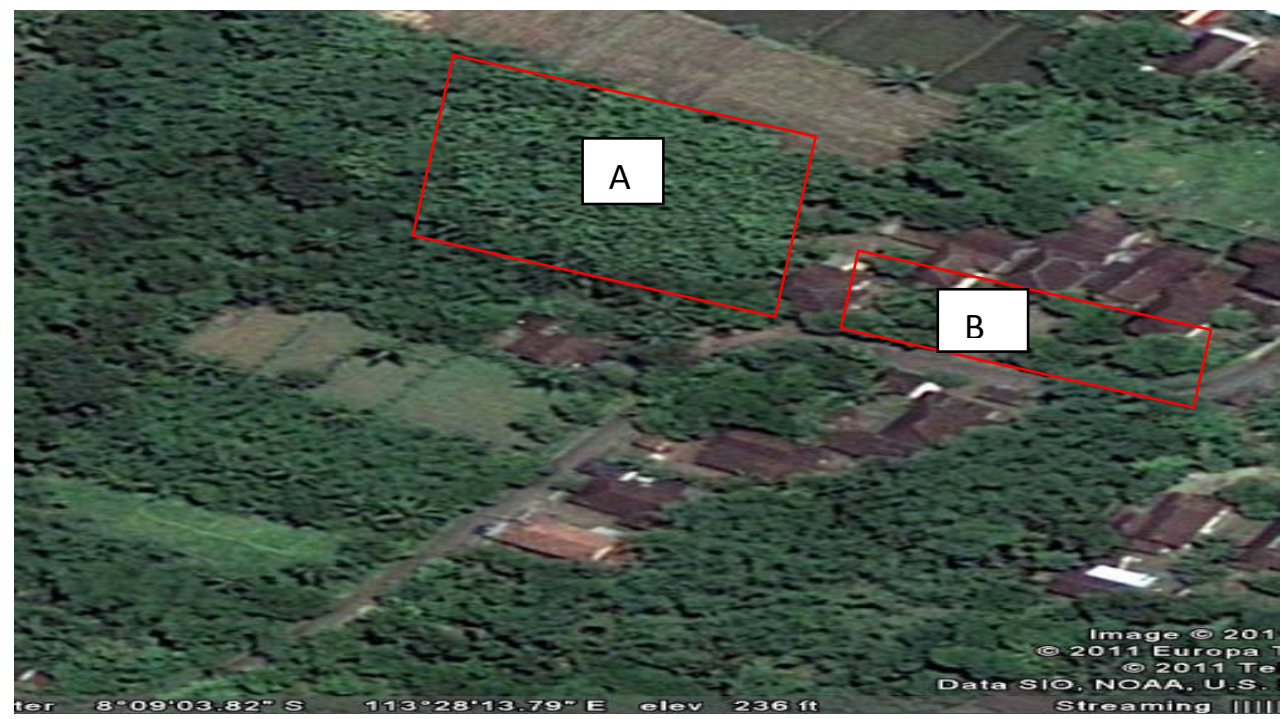


Gambar 1. Denah Lokasi Penelitian di Jember penelitian lahan Porang (A) dan non Porang (B).

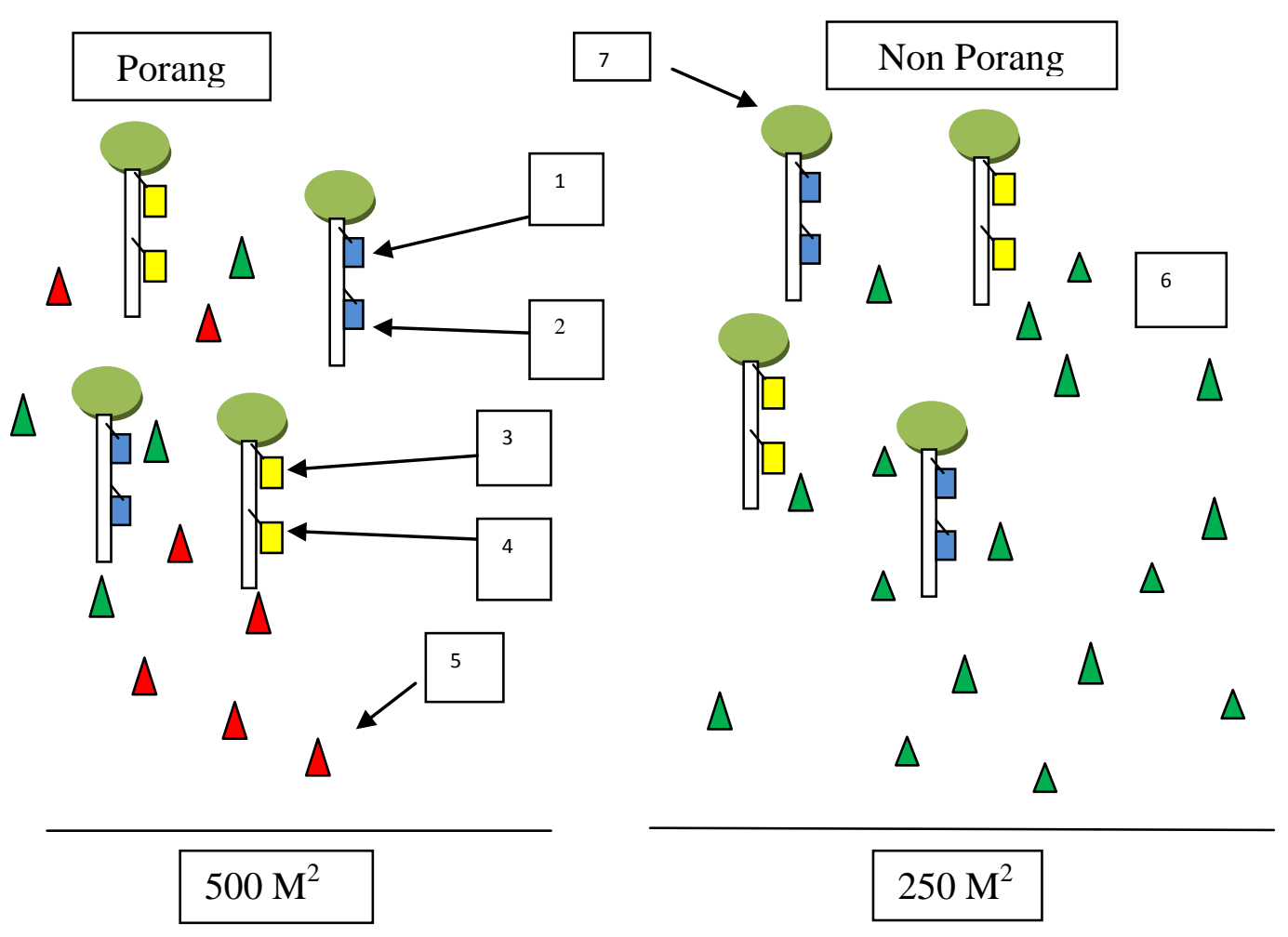

Gambar 2. Skema Denah Penelitian

HASIL

Arthropoda kanopi yang dikoleksi pada lokasi lahan Porang memiliki kelimpahan yang lebih rendah (329 individu) sedangkan pada lokasi lahan non Porang Arthropoda kanopi yang dikoleksi memiliki kelimpahan lebih tinggi (829 individu). Perolehan hasil individu Arthropoda kanopi tertinggi didapatkan lebih banyak pada bejana berwarna kuning dan pada ketinggian bagian kanopi atas pada lahan non budidaya Porang dibandingkan dengan lahan budidaya Porang. Nilai indeks keanekaragaman Arthropoda kanopi diperoleh pada lahan non Porang lebih besar (2.56) dibandingkan dengan lahan Porang (2.05). Kelimpahan Arthropoda kanopi antar dua lokasi, warna dan ketinggian berbeda nyata dengan $\mathrm{P}<0.05$. Kesamaan antara dua komposisi Arthropoda kanopi pada lahan budidaya
Porang dan non budidaya Porang dengan indeks Bray Curtis sebesar $0.60 \%$ Struktur komunitas pada lahan Porang didominasi oleh spesies Simulium sp. dengan nilai INP $22.42 \%$ sedangkan pada lahan non Porang didominasi oleh spesies Oxyopes sp. dengan nilai INP 20.75\%. Jumlah dan jenis vegetasi non crop serta diameter pohon pada lahan non budidaya Porang memiliki nilai lebih besar dibandingkan dengan lahan budidaya Porang. Analisis faktor lingkungan suhu udara dan intensitas cahaya terhadap kelimpahan Arthropoda kanopi didapatkan korelasi yang positif dan berdampak secara signifikan dengan korelasi P-value < 0.05. Rekomendasi kepada petani untuk pengelolaan lahan secara baik adalah vegetasi non crop di area tanaman budidaya tidak dibersihkan dan tidak melakukan penyemprotan pestisida. 


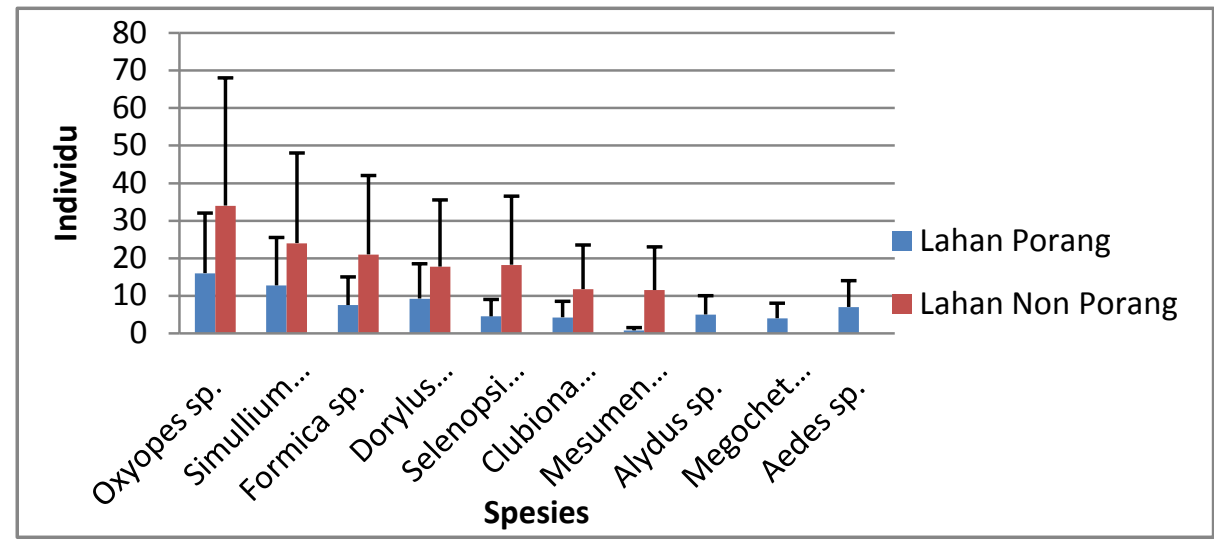

Gambar 3. Rata- rata kelimpahan Arthropoda Kanopi pada Kebun Berbasis Sengon Laut (Paraserianthes falcataria) dengan Tanaman Budidaya Porang dan Non Budidaya Porang.

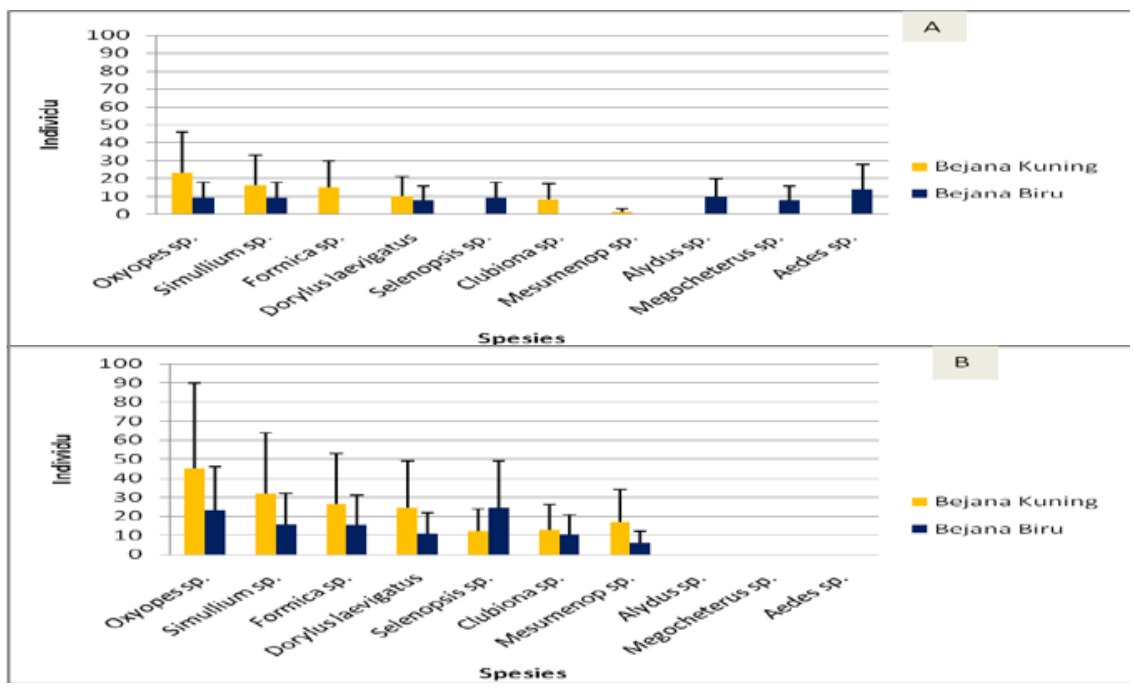

Gambar 4. Rata-rata Kelimpahan Arthropoda kanopi pada Kebun Berbasis Sengon Laut (Paraserianthes falcataria) di Bejana Berwarna Kuning dan Biru pada Lahan Budidaya Porang (A) dan Non Budidaya Porang (B).

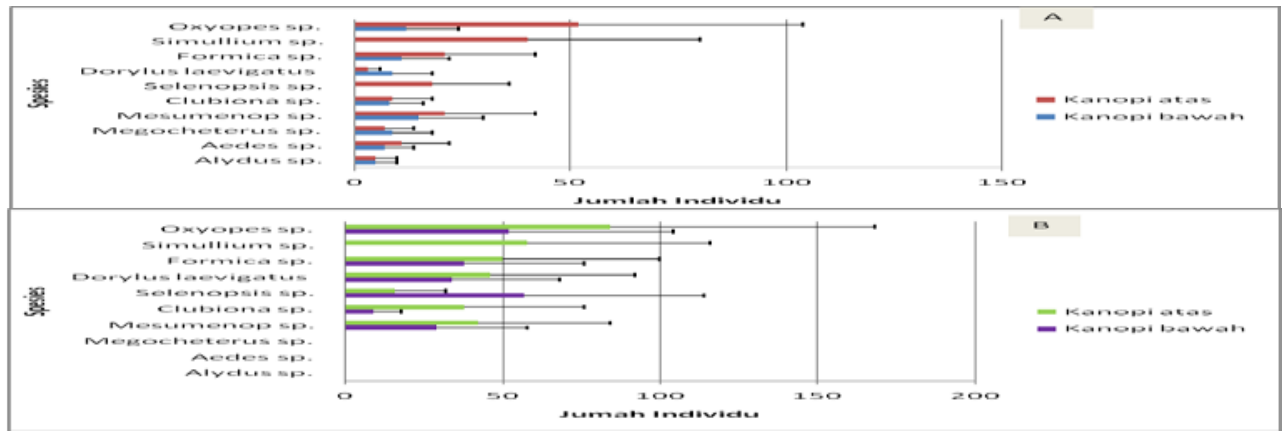

Gambar 5 Rata-rata Kelimpahan Arthropoda Kanopi pada Kebun Berbasis Sengon Laut (Paraserianthes falcataria) di Kanopi Atas dan Kanopi Bawah pada Lahan Budidaya Porang (A) dan Non Budidaya Porang (B). 


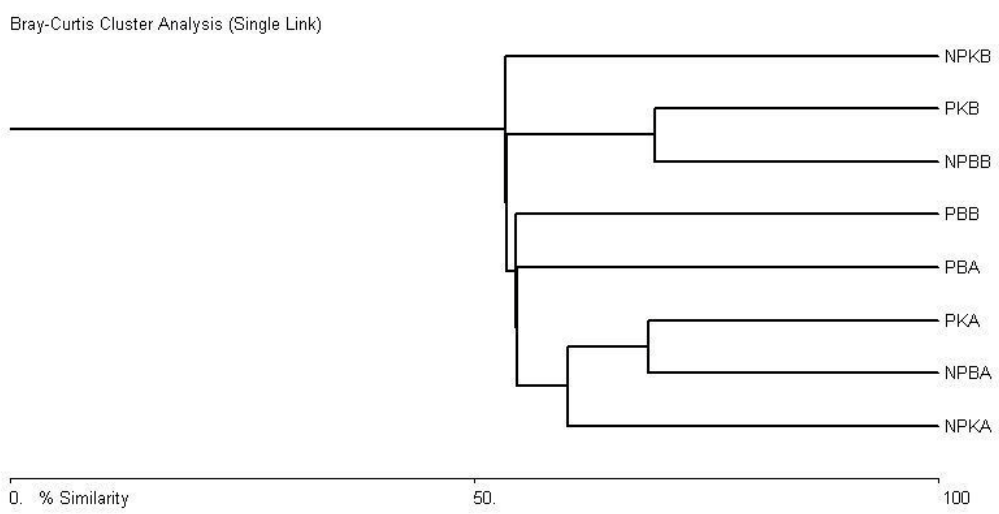

Gambar 6. Dendogram Pohon Kesamaan Komposisi Arthropoda Kanopi Sengon Laut antar Lokasi pada Masing-masing Bejana.

Tabel 6. Rangkuman nilai $\mathrm{F}$ diikuti dengan tingkat signifikansi analisis varians (Anova) GLM multivariate kelimpahan dan diversitas Arthropoda kanopi ( $\mathrm{N}=95)$.

\begin{tabular}{|l|l|l|l|l|l|l|}
\hline Spesies & $\begin{array}{l}\text { Lokasi } \\
(\mathbf{a})\end{array}$ & $\begin{array}{l}\text { Ketinggian } \\
(\mathbf{b})\end{array}$ & $\begin{array}{l}\text { Warna } \\
(\mathbf{c})\end{array}$ & $\begin{array}{l}\text { Interaksi } \\
(\mathbf{a x b})\end{array}$ & $\begin{array}{l}\text { Interaksi } \\
(\mathbf{a x c})\end{array}$ & $\begin{array}{l}\text { Interak } \\
\text { si (bxc) }\end{array}$ \\
\hline Oxyopes sp & 55.79 & 32.63 & 32.63 & 1.74 & 15.64 & 0.19 \\
\hline Simullium sp & 14.57 & 17.56 & 22.55 & 1.47 & 3.82 & 0.42 \\
\hline Formica sp & 59.83 & 37.29 & 56.80 & 1.49 & 8.12 & 1.49 \\
\hline Dorylus laevigatus & 49.91 & 8.20 & 35.04 & 0.33 & 13.16 & 2.95 \\
\hline Selenopsis sp & 63.96 & 9.33 & 17.78 & 0.02 & 0.53 & 39.10 \\
\hline $\begin{array}{l}\text { Keanekeragaman } \\
\text { Spesies }\end{array}$ & 211.73 & $414.83^{*}$ & $516.43^{\star}$ & 44.21 & 0.17 & 0.53 \\
\hline Kelimpahan & $389.81^{*}$ & 201.39 & 289.71 & 17.15 & 120.31 & 0.17 \\
\hline
\end{tabular}

\section{PEMBAHASAN}

Perbedaan kelimpahan populasi Arthropoda kanopi Sengon Laut berhubungan dengan kemampuan berkembang biak Arthropoda, sifat mempertahankan diri dan daur hidup Arthropoda. Kelimpahan Arthropoda juga dipengaruhi oleh hadirnya predator, patogen, parasit dan sebagainya. Faktor abiotik lingkungan seperti kelembaban udara, curah hujan, penyinaran, dan kecepatan angin yang ada di lahan budidaya Porang dan lahan non budidaya Porang yang dapat menyebabkan naik turunnya kelimpahan populasi di setiap tempat. Ekosistem setempat yang telah banyak mengalami tekanan-tekanan secara fisik seperti pengelolaan lahan yang tidak tepat guna yaitu penyemprotan dengan menggunakan pestisida dan penyiangan vegetasi non crop sebagai parameter ekosistem binaan disekitar lahan menyebabkan ketidakstabilan ekosistem menjadi terganggu dan mempengaruhi kelimpahan Arthropoda kanopi (Maswar, 2008).

Pada lahan non budidaya Porang memiliki jumlah vegetasi non crop yang dan ukuran pohon yang lebih beranekaragam dibandingkan pada lahan Porang yang memiliki jenis vegetasi non crop lebih sedikit. Keanekaragaman spesies vegetasi non crop pada lahan non budidaya Porang yang lebih banyak dibandingkan pada lahan Porang memberikan kontribusi yang besar 
terhadap jumlah kelimpahan dari Arthropoda kanopi Sengon Laut. Semakin tinggi keanekaragaman dari vegetasi non crop maka semakin beranekaragam juga spesies dan peran dari Arthropoda kanopi. Interaksi antara tumbuhan berkayu, semak, vegetasi non crop dengan Arthropoda kanopi sangat berkaitan erat dan sebagian besar Arthropoda makan tumbuh-tumbuhan, akan tetapi hanya sebagian kecil yang dianggap hama (Nurindah, 2002).

Interaksi antara tanaman dan Arthropoda kanopi terjadi secara komplek dan berlangsung sangat lama dan terus-menerus. Tanaman mengembangkan sistem pertahanan diri terhadap serangan Arthropoda kanopi sementara Arthropoda berupaya untuk mengembangkan sistem adaptasi untuk dapat mengatasi sistem pertahanan tanaman (Samsudin, 2008). Tumbuhan liar yang dapat menyediakan habitat bagi musuh alami yang dikenal juga sebagai refugia. Tumbuhan refugia adalah beberapa jenis tumbuhan di sekitar pertanaman yang dapat menyediakan tempat perlindungan, sumber pakan atau sumberdaya yang lain.

Spesies Arthropoda kanopi memiliki preverensi tersendiri dalam menanggapi biasan panjang gelombang warna yang dipantulkan dari bejana berwarna kuning dan bejana berwarna biru, sehingga diperoleh Arthropoda kanopi yang hanya ditemukan pada bejana berwana kuning dan hanya didapatkan pada bejana berwarna. Menurut Jumar (2000), Arthropoda memiliki preferensi terhadap warna dan bau, famili-famili pada ordo Arachnida (laba-laba), Diptera dan beberapa famili dari ordo Coleoptera memiliki kesukaan terhadap warna yang kontras, sehingga dimungkinkan mangsa yang didapatkan lebih banyak karena tertarik terhadap warna yang kontras tersebut (Faasch (1968) dan Gebert (1991) dalam
Buchholz et al., 2010). Menurut taktik pengendalian hama secara terpadu salah satu cara mengendalikan organisme pengganggu tanaman adalah secara mekanik dengan menggunakan alat perangkap (Oka, 1995). Salah satu jenis perangkap yang efektif dan sering digunakan dalam penelitian adalah jenis perangkap warna yaitu warna kuning dan biru. Jenis perangkap warna kuning ini didasari sifat serangga yang menyukai warna kuning mencolok dan warna kuning mirip warna kelopak bunga yang sedang mekar sempurna. Perangkap kuning dan biru efektif untuk memikat hama golongan thrips, aphid, kutu, dan tungau serta dijadikan indikator populasi hama di sekitarnya (Chu et al., 2003).

Leksono (2005), penelitian tentang preferensi warna disebutkan bahwa beberapa kelompok herbivor dan predator memiliki kesamaan dalam pemilihan warna yaitu warna kuning. Secara umum, respon positif terhadap preferensi warna kuning menunjukkan bahwa warna tersebut berhubungan dengan serangga yang memanfaatkan atau berhabitat pada daun-daunan. Karena preferensi warna menujukkan adanya ketertarikan terhadap aktivitas serangga yang akan dilakukan di sekitar warna tersebut, seperti adanya serangga herbivor, schavenger ataupun serangga predator yang memanfaatkan dedaunan secara tidak langsung sebagai habitat mencari mangsa di sekitar daun tersebut (Kirk, 1984 dalam Leksono ${ }^{3}$ et al., 2005).

Lokasi lahan non budidaya Porang diperoleh angka keanekaragaman yang lebih besar dibandingkan dengan lahan budidaya Porang. Leksono (2007), keanekaragaman spesies merupakan jumlah total proporsi suatu spesies relatif terhadap jumlah total individu yang ada, sehingga semakin seimbang proporsi jumlah spesies yang menunjukkan keanekaragaman yang semakin tinggi. 
Keanekaragaman Arthropoda kanopi antar dua lokasi, warna dan ketinggian didapatkan hasil perhitungan indeks Shannon-Wiener berkisar sebesar 2.052.56 berturut-turut untuk lahan budidaya Porang dan non budidaya Porang, sehingga kestabilan lingkungan pada kedua komunitas tersebut memiliki kestabilan sedang. Barbour et al,. (1987), indeks keanekaragaman ShannonWiener dapat digunakan sebagai salah satu indeks untuk mengukur heterogenitas suatu komunitas yang dapat menentukan kestabilan lingkungan komunitas tersebut. ).

Komposisi jenis kelompok predator lebih tinggi didapatkan pada lahan Porang dan Non Porang dibandingkan dengan Arthropoda kanopi jenis lain. Predator yang dominan adalah ordo Arachnida, Hymenoptera, Coleoptera dan Diptera. Keberadaan predator dalam agroekosistem akan sangat membantu peningkatan stabilitas dalam komunitas arthropoda melalui proses predasi yang dilakukannya. Predator memainkan peran menonjol dalam aliran energi melalui komunitas, merupakan pengatur populasi mangsanya, mendorong populasi mangsa untuk memiliki kemampuan bertahan hidup dan mewariskan pada keturunannya serta merupakan agen dalam proses ekologi mangsanya.

Keberadaan predator yang cukup tinggi mungkin juga erat kaitannya dengan tingginya populasi detrivora yang dapat berfungsi sebagai sumber pakan/mangsa alternatif predator (Mahrub, 1997). Hal itu sesuai dengan sifat predator yang pada umumnya polifag sehingga mampu bertahan hidup tidak hanya tergantung memangsa dari golongan herbivora saja (Gatot, 2007). Oxyopes sp. termasuk dalam ordo Arachnida, hewan Arthropoda kanopi ini bersifat predator dan bergerak aktif tanpa membuat sarang serta dapat mengejar mangsanya di atas daun-daun dengan kecepatan yang tinggi. Sifat yang aktif tersebut menyebabkan hewan ini mampu bertahan hidup dan berkembangbiak sehingga keberadaanya mampu mendominasi suatu komunitas, selain itu hewan ini mampu menghasilkan telur dalam jumlah banyak yang diletakkan di dedaunan. Heterogentas ruang dapat menyebabkan perbedaan tingkat keanekaragaman spesies pada suatu habitat. Arthropoda yang hidup di lahan Porang menempati habitat yang homogen dan dikendalikan oleh manusia, sehingga keanekaragamannya cenderung berbedabeda antara satu tempat dengan tempat yang lain dalam satu ekosistem.

\section{KESIMPULAN}

Secara umum hasil penelitian yang diperoleh adalah kelimpahan dan komposisi dari Arthropoda kanopi pada lahan non Porang memiliki nilai yang lebih tinggi dibandingkan pada lahan Porang, hal ini dapat disebabkan karena adanya vegetasi non crop dan jenos pohon yang berlimpah pada lahan non Porang serta faktor abiotik yang mendukung dan secara keseluruhan nilai diversitas tertinggi diperoleh pada lahan non Porang yaitu 2.56, sehingga dapat dikatakan keanekaragamannya dalam kategori sedang. Hasil penelitian ini dapat memberikan gambaran bahwa pentingnya keberadaan non crop di area tanaman budidaya yang saling berkaitan dengan habitat dari Arthropoda kanopi. Selama ini masih banyak masyarakat atau petani menganggap bahwa vegetasi non crop yang ada di sekitar area tanaman budidaya merupakan sumber hama dan penyakit tanaman, dari hasil penelitian ini terungkap bahwa vegetasi non crop digunakan sebagai habitat, tempat berlingdung, dan reservoir Arthropoda kanopi. 


\section{DAFTAR RUJUKAN}

Altieri MA, Nicholls CI. 2004. Biodiversity and Pest management in Agroecosystem. Second Edition. New York: Food Product Press.

Angulo-Sandoval, P. \& Aide, T.M. (2000) Effect of plant density and light availability on leaf damage in Manilkara bidentata (Sapotaceae). Journal of Tropical Ecology, 16, 447-464.

Barbour, M.G., J.H. Burk, and W.D. Pitts. 1987. Terrestrial Plant Ecology. Chapter 9: Method of sampling the plant community. Menlo Park, Benjamin/Cummings Publishing Co. CA.

Basset Y. 2001. Invertebrates in the canopy of tropical rain forests. Plant Ecology.

Basset Y., Hammond, P.M., Barrios, H., Holloway, J.D. and Miller, S. E (2003). Vertical and stratification of arthropod assemblages. Arthropods of tropical forest. Cambridge University Press. Cambridge.

Basset, Y., Hammond, P.M., Barrios, H., Holloway, J.D. \& Miller, S.E. (2003) Vertical stratification of arthropod assemblages. Arthropods of Tropical Forests-Spatiotemporal Dynamics and Resource Use in the Canopy (ed. by $\mathrm{Y}$. Basset, V. Novotny, S.E. Miller and R.L. Kitching), pp. 17-28. Cambridge University Press, Cambridge, U.K.

Borror,D.J., Triplehorn,C.A., dan Johnson, N.F. 1992. An Introduction to the study of Insect. Sounders College Publising, New York.

Gatot Mudjiono, Hagus Tarno, Slamet Rahardi Prihadianto. 2007. The Biodiversity of Arthropods In Orchid Plantation With Different
Altitude Field. Jurusan Hama dan Penyakit Tumbuhan Fakultas Pertanian Universitas Brawijaya.

Leksono $^{1}$, A. S., N. Nakagoshi, and Y. Isagi. 2005. The Effects of Forest Disturbances on Flying Insect Assemblages in Trawas, East Java. Tropics Vol. 14.

Noble,E.R. dan Noble G.A. 1989. Parasitilogi, Biologi Parasit Hewan Edisi Ke Lima. Yogyakarta: Gadjah Mada University Press.

Nurindah, D.A. Sunarto, IG.A.A. Indrayani, M. Rizal, Sri-Hadiyani, Subiyakto, dan Sujak. 2002. Optimalisasi pemanfaatan musuh alami dalam pengendalian hama utama kapas. Laporan Hasil Penelitian, Bagpro Penelitian PHT ADB 2 Malang. 13p.

Scholwalter, T.D., Yanli Zhang, and Robert A. Progar. 2005. Canopy Arthropod Response To Density and Distribution of Green Trees Retained after Partial Harvest. Ecological Applicants, 15(5). Pp 1594-1603.

Speight, M. R. and Wylie, F.R. (2001). Insect Pest in Tropical Forestry. Wallingford : CABI.

Syafei, E.S. 1990. Pengantar Ekologi Hewan. Bandung: Jurusan Biologi FMIPA ITB.

Syamsuri, I. 1993. Pengetahuan Lingkungan. Malang: IKIP Malang.

Soegianto, A. 1994. Ekologi Kuantitatif Metode Analisis Populasi dan Komunitas. Surabaya: Usaha Nasional.

Suhardi, S. Astuti, Minarnigsih, S. Sambas. H.D Dwijono, dan A. Widodo. 2002. Hutan dan Kebun 
sebagai sumber Pangan Nasional. Kanisius. Yogyakarta. Hal : 25-124.

Tonucci, R. G., Nair, P. K. R., Nair, V. D., Garcia, R., and Bernardino, F. S. 2011. Soil carbon storage in silvopasture and related land-use.

Takimoto, A., Nair, V. D., and Nair, P. K. R. 2009. Soil carbon sequestration potential of agroforestry practices in the West African Sahel. Journal of Environmental Quality Agroforestry Systems 76: 11-25.

Takimoto, A., Nair, P. K. R., and Alavalapati, J. R. R. 2008. Socioeconomic potential of carbon sequestration through agroforestry in the West African Sahel. Mitigation and Adaptation of Strategies for Global Change 13: 745-761.

Wallis, C. M. S. J. Fleischer, D. Luster, F. e. Gildo 2005. Aphid (Hemiptera: Aphididae) Species
Composition and Potential Aphid Vectors of Plum Pox Virus in Pennsylvania Peach Orchards. The Horticulture and Food Research Institute of New Zealand Limited, Old Mill Road, RD3 Motueka 7198, New Zealand 2008.

Wallis,D.R., and Shaw. P.W. 2008., Evaluation of Coloured Sticky Traps For Monitoring Beneficial Insect in Apple Orchards. The Horticulture and Food Research Institute of New Zealand Limited, Old Mill Road, RD3 Motueka 7198, New Zealand 2008.

Winchester, N.N., 1997. Canopy arthropods of coastal Sitka spruce trees on Vancouver Island, British Columbia, Canada. Pp. 151-168 In N.E. Stork, J.A. Adis, and R.K. Didham, (Eds.), Canopy Arthropods , Chapman and Hall, London. 